\title{
Henna tetováž
}

\author{
prof. MUDr. Zdeněk Doležel, CSc. ${ }^{1}$, MUDr. Pavlína Autratová2 ${ }^{2}$ MUDr. Lucia Marušiaková, Ph.D. ${ }^{2}$ \\ 'Pediatrická klinika LF MU a FN Brno \\ ${ }^{2}$ Dětské kožní oddělení Pediatrické kliniky LF MU a FN Brno
}

\begin{abstract}
Klíčová slova: alergická kontaktní dermatitida, henna, tetování černou hennou.
Key words: allergic contact dermatitis, henna, black henna tattoo.
\end{abstract}

Šestnáctiletá dívka si v posledním týdnu pobytu v Egyptě nechala udělat na dorzální straně levého předloktí tetování hennou, které bylo po 5 dnech ještě zopakováno pro trvalejší konečný efekt. Po návratu domů a celkově s odstupem 5 dnů od druhého tetování začala dívka v místech tetováže pocitovat napětí, pruritus a mírnou bolestivost. Krátce po těchto iniciálních přiznacích došlo k výrazné změně vytetovaného obrazce, kdy prakticky v celém jeho rozsahu byly prítomny četné papuly a pustuly, makulózní morfy byly i na dorzální straně ruky a také na edematózně prosáklých článcích prstů (obrázek 1); levé předloktí bylo mírně edematózní (rozdíl mezi obvodem pravého a levého předloktí byl $+2 \mathrm{~cm}$ ve prospěch strany levé) a nebolestivé na pohmat. Kromě uvedené změny kưže byl celkový fyzikální nález u afebrilního děvčete bez odchylek, lymfadenopatie v oblasti levé loketní jamky a levé axily nebyla prítomna. Hodnoty základních laboratorních analýz byly zcela normální. S ohledem na anamnestické údaje a lokální kožní nález jsme stav hodnotili jako alergickou kontaktní dermatitidu po tetování hennou.

Henovník bílý (Lawsonia inermis), česky též henna bílá, je rostlina dosahující průměrné výšky $3 \mathrm{~m}$ a její domovinou jsou tropické a subtropické oblasti Afriky a Asie. Komerčně je plodina pěstována nejvíce v Indii, Pákistánu, Libyi, Maroku, Íránu a Afghánistánu. Hladké dlouhé listy rostliny se suší a jejich drcením se získává hnědočervený
Obr. 1. Výrazně plastická papulopustulózní alergická reakce po tetování hennou

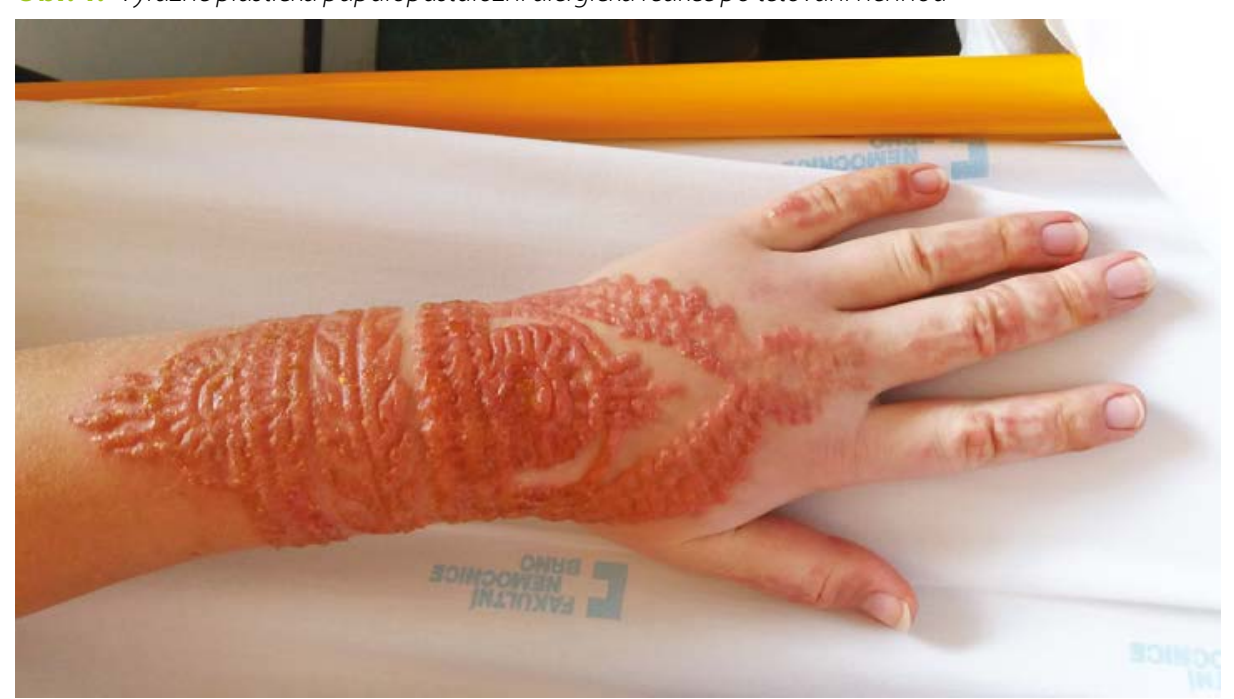

nebo zelený prášek, tzv. přirodní henna (pure henna), jehož barevné pigmenty se dobře váží s proteiny. Po smíchání prírodní henny s vodou a některými oleji vzniká hustá pasta, která se tradičně využívá ke zdobení kủže, vlasů či nehtů zejména mezi vyznavači muslimského a hinduistického náboženství. V zemích, kde se henna tradičně pěstuje, bývá ve své „pure“ formě používána také při různých chorobách kưže. Podobně jako u jiných barviv může i po aplikaci prírodní henny na kưǔi člověka dojít k alergické reakci, je to však poměrně vzácné. Malování/tetování prírodní hennou má dočasný efekt a obvykle na kưži vydrží 28 dnů. S mohutným rozvojem turismu do zemí, kde se henovník prirozeně vyskytuje, dochází k tomu, že mnoho turistů, zejména pak adolescentního věku, si nechává hennou tetovat na kůži těla různé obrazce, nápisy apod. Ve srovnání s klasickým tetováním, jak je známe v našich podmínkách, je tetování hennou vlastně malováním a je atraktivní, nebot' je bezbolestné, levné, nehrozí při něm príp. infekce HIV/hepatitida, zájemci jsou často tetováni přímo na pláži u moře nebo u hotelového bazénu. Ke zdobení kưže je však v těchto prípadech používána tzv. černá henna, kdy do prírodní henny místní „mistři tatérii” přidávají kromě oleje další prrísady (např. citronovou štávu, vinný ocet, soli niklu/kobaltu/olova/chromu, parafenyldiamin /PPD/). A to proto, aby tetované obrazce byly zretelněji vidět a zejména, aby na kưži déle vydržely. Turisté se tak mohou po návratu domů pochlubit svému 
okolí vytetovaným „suvenýrem“. Bohužel většinou právě až po návratu domů nezrídka dochází k tomu, že v místech tetováže se rozvine i těžká lokální dermatitida. Jde o alergickou reakci nejčastěji právě na složku PPD. Směs z černé henny používaná k tetováži nemá žádné standardní složení, každý tetující používá svůj recept a obsah zejména PPD může být extrémně vysoký.
K lokální alergické reakci obvykle dochází po 3-10 dnech od malování černou hennou. Vzácně může být kožní reakce doprovázena rozvojem celkové infekce, která se do organismu dostává přes postiženou kůži. K lokální léčbě dermatitidy se používají dermatologika obsahující kortikoidy, ale i antibiotika, celkově pak antihistaminika, príp. kortikoidy. Terapii by měl koordinovat erudova- ný dermatolog, s kterým je možno konzultovat príp. test přecitlivělosti na PPD. I přes intenzivní léčbu mohou být rezultátem dermatitidy ložiska hypo-/hyperpigmentace, hypertrichózy, ale také keloidní jizvy. Zcela se vyhnout tetování černou hennou je racionální a účinnou prevencí nejen alergické kožní reakce, ale i možných trvalých kosmetických defektů. 